\title{
HIGHER CTX-M, TEM, AND SHV EXTENDED-SPECTRUM BETA-LACTAMASE PLASMID GENE COMBINATION FREQUENCY IN ESBL PRODUCING KLEBSIELLA PNEUMONIAE COMPARED WITH ESBL PRODUCING ESCHERICHIA COLI
}

\author{
Vita Skuja ${ }^{1}$, Katrīna Pekarska ${ }^{2}$, Aleksejs Derovs ${ }^{3}$, Ludmila Vīksna ${ }^{4}$, Linda Piekuse ${ }^{5}$, \\ Inga Kempa $^{6}$, Una Caune ${ }^{7}$, Dace Rudzīte ${ }^{8}$, Aivars Lejnieks', Angelika Krūmiṇa ${ }^{10}$
}

\begin{abstract}
Introduction: Extended-spectrum beta-lactamase (ESBL) producing Enterobacteriaceae confer antibiotic resistance to broad-spectrum penicillins, cephalosporins, using ESBL genes CTX-M, TEM, SHV, which are encoded in bacterial plasmid genome.
\end{abstract}

Methods: We compared plasmid CTX-M, TEM, and SHV ESBL gene combinations in ESBL producing Escherichia coli and Klebsiella pneumoniae. Altogether, 136 ESBL producing Enterobacteriaceae isolation cases were analyzed.

Results: The ESBL producing Enterobacteriaceae, mostly $K$. pneumoniae $(\mathrm{n}=66 ; 48.53 \%)$, E. coli $(\mathrm{n}=36$; $26.47 \%)$, were isolated from $52(38.2 \%)$ female and $84(61.8 \%)$ male patients from Riga East Clinical University Hospital. Overall, 132 isolates (97.06\%) registered positive for the plasmid CTX-M gene, 97 isolates (71.32\%) for the plasmid TEM gene, and 87 isolates (63.97\%) for the plasmid SHV gene. Patients with the three ESBL plasmid gene (CTX-M+ TEM+ SHV+) combination were significantly older $(67.11 \pm 14.16$ years $)$ than patients with other gene combinations $(59.63 \pm 18.14$ years; $\mathrm{p}=0.047)$. Plasmid SHV gene frequency was higher in $K$. pneumoniae $(\mathrm{p}<0.001)$. The $K$. pneumoniae mostly presented with the three plasmid ESBL gene $(\mathrm{CTX}-\mathrm{M}+$ $\mathrm{TEM}+\mathrm{SHV}+)$ combination, whereas $E$. coli presented with other gene combinations $(\mathrm{p}=0.014)$.

Conclusions: Klebsiella Pneumoniae, more often, presented with the plasmid SHV ESBL gene and the three ESBL gene (CTX-M+ TEM+ SHV+) combination, compared to E. coli. Older patients with ESBL producing Enterobacteriaceae infection, more often, presented with the three ESBL gene $(\mathrm{CTX}-\mathrm{M}+\mathrm{TEM}+\mathrm{SHV}+)$ combination, compared to younger patients with the infection.

UDC Classification: 615 DOI: http://dx.doi.org/10.12955/cbup.v4.841

Keywords: Extended-spectrum beta-lactamase, CTX-M, TEM, SHV, Klebsiella pneumonia, Escherichia coli.

\section{Introduction}

Since the first outbreak in 1983, reports of extended-spectrum beta-lactamase (ESBL) producing Enterobacteriaceae have increased due to extensive antibiotic consumption and widespread gene mutation, conferring resistance to extended spectrum penicillins and cephalosporins (Coque, Baquero, \& Canton, 2008; Alekshun \& Levy, 2007).

Extended-spectrum beta-lactamase are mostly produced by Escherichia coli and Klebsiella pneumoniae (Shaikh, Fatima, Shakil, Rizvi, \& Kamal, 2015; Lee, Bae, \& Lee, 2012; Cantón et al., 2008) and their production is determined by the presence of three extended-spectrum beta-lactamase

\footnotetext{
${ }^{1}$ Vita Skuja, Riga East Clinical University Hospital, Riga Stradins University, Department of Internal Medicine, Riga, Latvia,vita@skuja.lv

${ }^{2}$ Katrīna Pekarska, Riga Stradins University, Department of Internal Medicine, Riga, Latvia

${ }^{3}$ Aleksejs Derovs, Riga East Clinical University Hospital, Riga Stradins University, Department of Internal Medicine, Riga, Latvia

${ }^{4}$ Ludmila Vīksna, Riga East Clinical University Hospital, Riga Stradins University, Department of Infectology and Dermatology, Riga, Latvia

${ }^{5}$ Linda Piekuse, Riga Stradins University, Scientific Laboratory of Molecular Genetics, Riga, Latvia

${ }^{6}$ Inga Kempa, Riga Stradins University, Scientific Laboratory of Molecular Genetics, Riga, Latvia

${ }^{7}$ Una Caune, University of Latvia, Riga, Latvia

${ }^{8}$ Dace Rudzīte, Riga East Clinical University Hospital, Riga, Latvia

${ }^{9}$ Aivars Lejnieks, Riga East Clinical University Hospital, Riga Stradins University, Department of Infectology and Dermatology, Riga, Latvia

${ }^{10}$ Angelika Krūmiņa, Riga East Clinical University Hospital, Riga Stradins University, Department of Infectology and Dermatology, Riga, Latvia
} 
genes: CTX-M, TEM, and SHV (Poirel, Naas, \& Nordmann, 2008) in the bacterial plasmid genome, each determining a specific resistance towards different antimicrobials (Shaikh et al., 2015; Lee et al., 2012; The New $\beta$-Lactamases - NEJM, 2015).

The ESBL producing microorganisms predominate in cases of urinary tract infections, ventilatorassociated pneumonias, wound infections, intra-abdominal infections, and a wide variety of other nosocomial and community acquired infections (Spadafino, Cohen, Liu, \& Larson, 2014; Takaba et al., 2014; Tacconelli et al., 2014).

Adequate empiric antibacterial therapy in ESBL producing microorganism infection cases should be started early, preferably within 72 hours of confirmation of ESBL producing bacteria (Tumbarello et al., 2007), and should be based on local antibacterial resistance patterns. This is often challenging due to high antimicrobial resistance and lack of local resistance pattern data (The New $\beta$-Lactamases NEJM, 2015 ; Peralta et al., 2012).

Plasmid CTX-M, TEM, and SHV genes, and their combinations, which determine antimicrobial resistance and clinical course severity, vary widely depending on the geographic location, hospital, ward, patient group, or even type of infection (Alekshun \& Levy, 2007; Shaikh et al., 2015; Lee et al., 2012; Cantón et al., 2008). Therefore, it is essential to determine the local ESBL producing bacteria strains and plasmid extended-spectrum beta-lactamase gene frequency in order to establish local resistance patterns and start an effective empiric antibacterial treatment (Tacconelli et al., 2014).

\section{Aim of the Study}

The aim of the study is to compare plasmid CTX-M, TEM, and SHV extended-spectrum betalactamase gene presence and combinations in ESBL producing E. coli and K. pneumoniae strains.

\section{Methods}

Setting and Study Design

A cross-sectional single-center study was conducted in Riga East Clinical University Hospital (RECUH), Latvia, the largest medical center (a 2270-bed center) in the Baltic countries.

Patient Selection and Sample Size

All consecutive ESBL producing Enterobacteriaceae cases were selected over a 6-month period (during 2013-2014). A total of 136 ESBL producing Enterobacteriaceae isolation cases, containing plasmid genes CTX-M, TEM, and SHV, were included in the study, regardless of patient age, gender, and clinical severity.

Demographic Data

Demographic data were gathered from medical records on "day" patients that were discharged, and this included information about the patient's age and gender.

Bacteriological Analysis

Bacteriological analysis was performed according to the European Committee on Antimicrobial Susceptibility Testing (EUCAST) guidelines (version 1.0, December 2013) for detection of resistance mechanisms and specific resistances of clinical or epidemiological importance or both (EUCAST: Resistance mechanisms, 2015). This analysis provided information about the tested biomaterial, including wound biomaterial, urine, bronchoalveolar fluid, abdominal cavity biomaterial, blood, abscess, cerebrospinal fluid, and sputum, as well as ESBL producing Enterobacteriaceae strains that were isolated during the study.

Genetic Analysis

Genetic analysis, analyzing only the acquired antibiotic resistance, provided information about the three most common bacterial plasmid extended-spectrum beta-lactamase genes: CTX-M, TEM, and SHV. Bacteria selected from ESBL producing colonies were grown in $2 \mathrm{ml}$ Lysogeny broth (LB) media at $37{ }^{\circ} \mathrm{C}$ overnight. Plasmid DNA were isolated by manufacturer protocol using E.Z.N.A. plasmid Mini Kit I (Omega Bio-Tek, USA). The presence of plasmid extended-spectrum betalactamase genes was confirmed by polymerase chain reaction (PCR), using gene specific primers as described in the literature (Edelstein, Pimkin, Palagin, Edelstein, \& Stratchounski, 2003; Wu et al., 2001). These PCR products were analyzed using $2 \%$ agarose gel. 
Statistical Analysis

An original study protocol was developed with 106 parameters, including demographic, bacteriological, and genetic parameter groups and completed for each ESBL producing Enterobacteriaceae isolation case; and used for database development using Microsoft Office Excel 2013 software. Statistical analysis was conducted with IBM SPSS 22.0 software using Spearman correlation coefficient, Mann-Whitney U test, and Pearson's Chi-square test. All p-values were twotailed and considered significant at 0.05 level.

\section{Results}

During the study, ESBL producing Enterobacteriaceae were isolated from 52 (38.2\%) female and 84 $(61.8 \%)$ male patients in the age range $22-89$ years; the mean age was $61.35 \pm 16.92$ (CI 95\%; 57.76 $-64.78)$ years.

Bacteriological Data

Most commonly, ESBL producing Enterobacteriaceae were isolated from wound $(n=44,32.35 \%)$, urine $(\mathrm{n}=25,18.38 \%)$, bronchoalveolar fluid $(\mathrm{n}=25,18.38 \%)$, and abdominal cavity $(\mathrm{n}=20$, $14.71 \%$ ) biomaterial. (Figure 1)

In most cases, ESBL producing K. pneumoniae ( $\mathrm{n}=66,48.53 \%)$, E. coli $(\mathrm{n}=36,26.47 \%)$, Enterobacter cloaceae $(\mathrm{n}=16,11.76 \%)$, and Proteus mirablis $(\mathrm{n}=12,8.82 \%)$ were isolated during the study (Figure 2).

Figure 1: Biomaterial for extended-spectrum beta-lactamase producing Enterobacteriaceae isolation, n $(\%)$

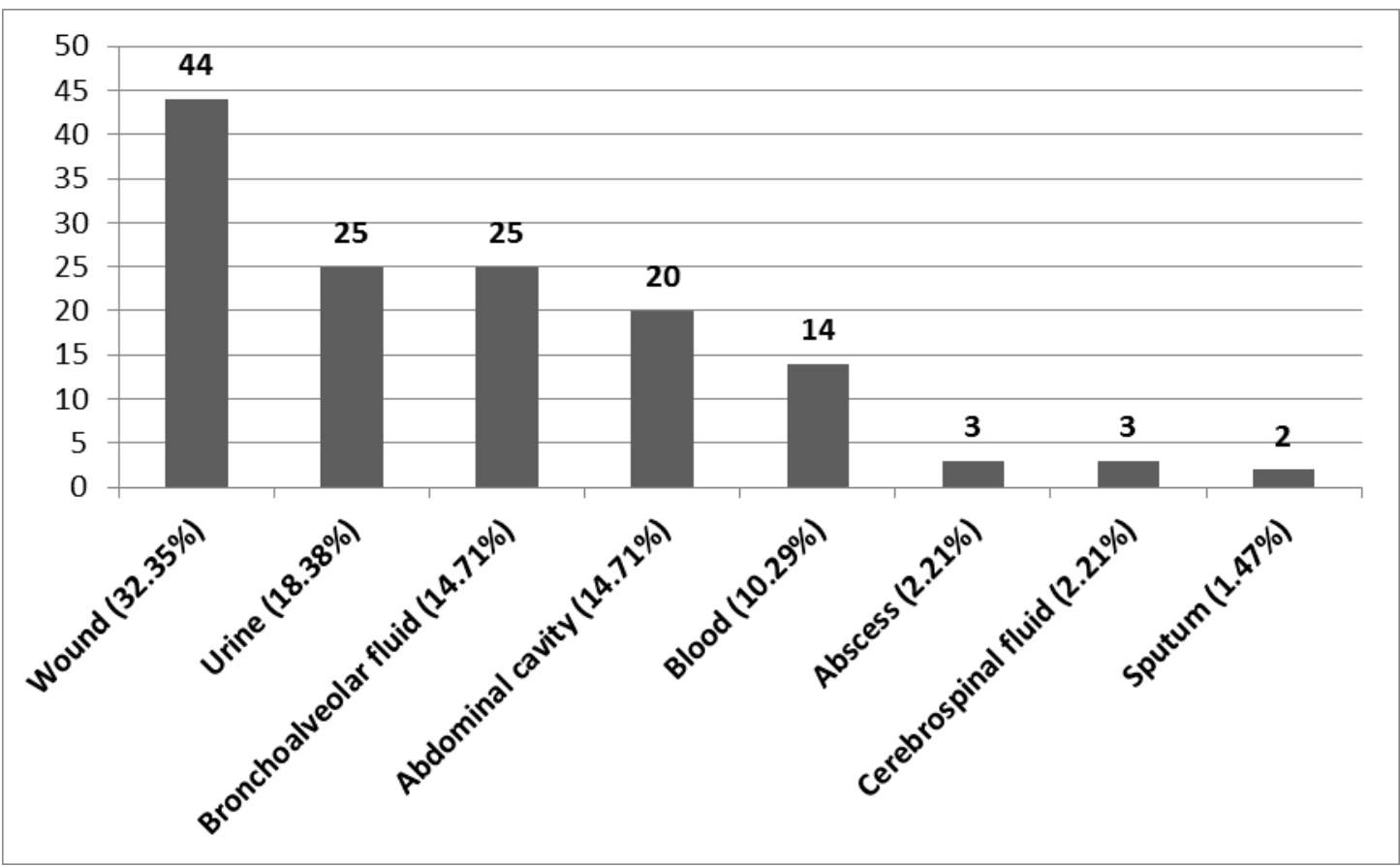

Source: Author 
Figure 2: Extended-spectrum beta-lactamase producing Enterobacteriaceae isolated in the study, $\mathrm{n}$ $(\%)$

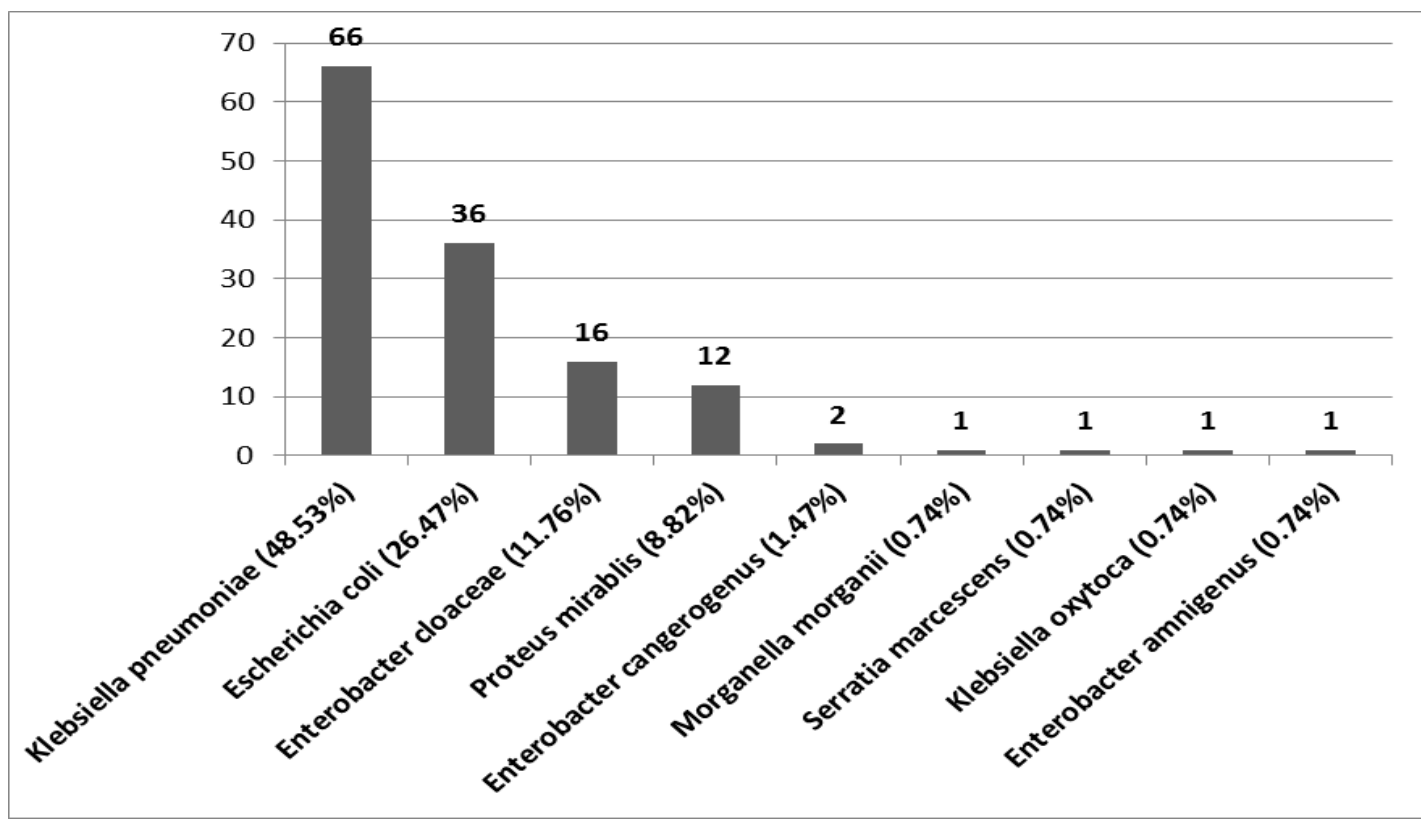

Source: Author

Genetic Profile

There were 132 ESBL producing Enterobacteriaceae isolates $(97.06 \%)$ that registerd positive for the plasmid CTX-M gene, 97 isolates $(71.32 \%)$ positive for the plasmid TEM gene, and 87 isolates (63.97\%) positive for the plasmid SHV gene.

In most cases ( $\mathrm{n}=62,45.59 \%)$, all three plasmid extended-spectrum beta-lactamase genes: CTX-M, TEM, and SHV, were detected in ESBL producing Enterobacteriaceae plasmid genome at the same time (Table 1).

Table 1: Results of extended-spectrum beta-lactamase producing Enterobacteriaceae extendedspectrum beta-lactamase plasmid gene detection, $\mathrm{n}(\%)$

\begin{tabular}{|c|c|c|}
\hline Gene combinations & N total (136) & \% \\
\hline CTX-M+ TEM+ SHV+ & 62 & 45.59 \\
\hline CTX-M+ TEM+ SHV- & 31 & 22.79 \\
\hline CTX-M+ TEM- SHV+ & 23 & 16.91 \\
\hline CTX-M+ TEM- SHV- & 16 & 11.77 \\
\hline CTX-M- TEM+ SHV+ & 2 & 1.47 \\
\hline CTX-M- TEM+ SHV- & 2 & 1.47 \\
\hline
\end{tabular}

Source: Author

Demographic Data Correlations

No statistically significant differences were found between male and female patient groups concerning bacterial and genetic factors (Table 2).

Patients with plasmid CTX-M+ TEM + SHV + gene combination were significantly older $(67.11 \pm$ 14.16 years; CI 95\%, 63.31-70.76 years) than patients with other plasmid gene combinations (59.63 \pm 18.14 years; CI 95\%, 55.61-63.70 years), including CTX-M+ TEM+ SHV-; CTX-M+ TEM- SHV+; CTX-M- TEM+ SHV+; CTX-M+ TEM- SHV-; and CTX- TEM+ SHV- plasmid gene combinations ( $p$ $=0.047)$. No other significant differences were found between the three plasmid extended-spectrum 
beta-lactamase genes and their combinations concerning patient age or gender. Also, no statistically significant differences were found between $K$. pneumoniae and E. coli patient groups in terms of age.

Bacteriological Data Correlations

Statistically significant differences were found between $K$. pneumoniae and E. coli groups in terms of plasmid SHV gene frequency, which was higher in the K. pneumoniae group, compared to the $E$. coli group $(\mathrm{p}<0.001)$. Statistically significant differences were also found in plasmid gene combinations, where $K$. pneumoniae mostly presented in the three plasmid CTX-M+ TEM $+\mathrm{SHV}+$ extendedspectrum beta-lactamase gene combination, whereas E. coli was evident in other plasmid gene combinations, including CTX-M+ TEM+ SHV-; CTX-M+ TEM- SHV+; CTX-M- TEM+ SHV+; CTX-M+ TEM-SHV-; and CTX- TEM+ SHV- plasmid gene combinations $(\mathrm{p}=0.014 ; \quad$ Table 3$)$.

Table 2: Bacteriological and genetic data (plasmid genes) comparison in male and female patients, $\mathrm{n}$ $(\%)$

\begin{tabular}{|c|c|c|c|}
\hline & $\begin{array}{c}\text { Male patients } \\
(\mathbf{n = 8 4 , 6 1 . 8 \% )}\end{array}$ & $\begin{array}{c}\text { Female patients } \\
(\mathbf{n = 5 2 , 3 8 . 2 \% )}\end{array}$ & p-value \\
\hline K. pneumoniae, n (\%) & $43(51.2 \%)$ & $23(33.2 \%)$ & 0.674 \\
\hline E. coli, n (\%) & $21(25 \%)$ & $15(28.8 \%)$ & 0.621 \\
\hline${\text { Other } \text { Enterobacteriaceae }^{\mathbf{a}}, \mathbf{n}(\%)}^{(\%)}$ & $20(23.8 \%)$ & $14(26.9 \%)$ & 0.684 \\
\hline CTX-M+, n (\%) & $81(96.4 \%)$ & $51(98.1 \%)$ & 0.580 \\
\hline TEM+, n (\%) & $57(67.9 \%)$ & $40(76.9 \%)$ & 0.256 \\
\hline SHV+, n (\%) & $55(65.5 \%)$ & $32(61.5 \%)$ & 0.642 \\
\hline CTX-M+ TEM+ SHV+, n (\%) & $39(46.6 \%)$ & $23(44.2 \%)$ & 0.860 \\
\hline $\begin{array}{c}\text { Other plasmid gene } \\
\text { combinations } \mathbf{b}, \mathbf{n}(\%)\end{array}$ & $45(53.6 \%)$ & $29(55.8 \%)$ & 0.860 \\
\hline
\end{tabular}

${ }^{a}$ E. cloaceae, P. mirablis, E. cancerogenus, M. morganii, S. marcescens, K. oxytoca, E. amnigenus

${ }^{\mathrm{b}}$ CTX-M+ TEM+ SHV-; CTX-M+ TEM- SHV+; CTX-M- TEM+ SHV+; CTX-M+ TEM- SHV-; and CTXTEM+ SHV-

Percentage stated within the gender group

Source: Author

Table 3: Genetic data comparison (plasmid genes) in different extended-spectrum beta-lactamase producing Enterobacteriaceae, n (\%)

\begin{tabular}{|c|c|c|c|c|}
\hline & $\begin{array}{c}\text { K. pneumoniae } \\
(\mathbf{n}=\mathbf{6 6}, \mathbf{4 8 . 5 3 \% )}\end{array}$ & $\begin{array}{c}\mathbf{E .} \text { coli } \\
(\mathbf{n = 3 6 ,} \\
\mathbf{2 6 . 4 7 \% )}\end{array}$ & p-value $^{\text {a }}$ & $\begin{array}{c}\text { Other }_{\text {Enterobacteriaceae }^{\boldsymbol{b}}} \\
(\mathbf{n}=\mathbf{3 4 , 2 5 \% )}\end{array}$ \\
\hline CTX-M+, n (\%) & $65(98.5 \%)$ & $36(100 \%)$ & 0.458 & $31(91.2 \%)$ \\
\hline TEM+, n (\%) & $46(69.7 \%)$ & $26(72.2 \%)$ & 0.789 & $25(73.5 \%)$ \\
\hline SHV+, n (\%) & $52(78.8 \%)$ & $15(41.7 \%)$ & $<\mathbf{0 . 0 0 1}$ & $20(58.8 \%)$ \\
\hline $\begin{array}{c}\text { CTX-M+ TEM+ } \\
\text { SHV+, n (\%) }\end{array}$ & $37(56.1 \%)$ & $11(30.6 \%)$ & $\mathbf{0 . 0 1 4}$ & $14(41.2 \%)$ \\
\hline $\begin{array}{c}\text { Other plasmid gene } \\
\text { combinations }\end{array}$ & $29(43.9 \%)$ & $25(69.4 \%)$ & $\mathbf{0 . 0 1 4}$ & $20(58.8 \%)$ \\
\hline
\end{tabular}

${ }^{a} \mathrm{p}$ values calculated comparing $K$. pneumonia and $E$. coli isolates

${ }^{\mathrm{b}}$ E. cloaceae, P. mirablis, E. cancerogenus, M. morganii, S. marcescens, K. oxytoca, E. amnigenus.

${ }^{\mathrm{c}} \mathrm{CTX}-\mathrm{M}+\mathrm{TEM}+\mathrm{SHV}-$; CTX-M+ TEM- SHV+; CTX-M- TEM+ SHV+; CTX-M+ TEM- SHV-; and CTXTEM+ SHV-

Percentage stated within the bacteria group.

Source: Author 


\section{Discussion}

Patients were approximately the same gender and age as described in other studies concerning ESBL producing Enterobacteriaceae infection with male patients around 60 years of age (Kassakian \& Mermel, 2014; Mehrgan \& Rahbar, 2008).

Klebsiella pneumoniae was the most frequently isolated ESBL producing bacteria in this study, whereas $E$. coli was the most commonly isolated ESBL producing bacteria in other literature sources (Sasirekha, 2013; Moor et al., 2008; Kargar, Kargar, Jahromi, Najafi, \& Ghorbani-Dalini, 2014). These differences may be explained by the various biomaterials used in the different studies. Wound biomaterial was the most common source of biomaterial for ESBL producing Enterobacteriaceae isolation in this study, while urine was the most commonly used biomaterial in other studies (Peralta et al., 2012; Kassakian \& Mermel, 2014; Moor et al., 2008; Ruiz de Alegría et al., 2011; Kolar et al., 2006). The frequency of other biomaterial for ESBL producing bacteria detection, including abdominal cavity and abscess biomaterial, bronchoalveolar fluid, blood, and cerebrospinal fluid was approximately the same as that described in other literature sources (Peralta et al., 2012; Kassakian \& Mermel, 2014; Ruiz de Alegría et al., 2011; Kolar et al., 2006; Mengistu et al., 2013). The frequency of other Enterobacteriaceae found in this study, including P. mirablis, S. marcescens, and K. oxytoca, was similar to that in other studies (Sasirekha, 2013). The frequency of Enterobacter spp., including $E$. cloaceae, E. cancerogenus, and E. amnigenus, was slightly higher in this study, compared to other literature sources (Sasirekha, 2013; Moor et al., 2008; Kargar et al., 2014).

The three most frequently found plasmid extended-spectrum beta-lactamase gene classes (CTX-M, TEM, and SHV) were analyzed in this study without further plasmid gene subgroup analysis. Plasmid CTX-M, TEM, and SHV extended-spectrum beta-lactamase gene frequency was higher in this study than in other literature sources, namely: 1) in this study plasmid CTX-M was $97.06 \%$ compared to $73.8-85.4 \%$ elsewhere; 2) plasmid TEM was $71.32 \%$ compared to elsewhere $42.4-62.3 \%$; and 3 ) plasmid SHV was $63.97 \%$ compared to the wide range of $7.7-62.3 \%$ in the literature (Hayakawa et al., 2013; Lin, Hsu, Chen, Huang, \& Lo, 2010; Manoharan, Premalatha, Chatterjee, \& Mathai, 2011). In addition, plasmid gene combination frequency was higher, compared to other similar studies: CTX$\mathrm{M}+\mathrm{TEM}+\mathrm{SHV}+$ plasmid gene combination $(45.59 \%$ vs $25.64 \%)$; and CTX-M+ TEM+ SHVplasmid gene combination (68.38\% vs 26.5-35.5\%; Hayakawa et al., 2013; Manoharan et al., 2011). Considerably higher plasmid gene frequency was found in this study compared to the literature for CTX-M+ TEM- SHV+ plasmid gene combination (63.5\% vs $4.7-5.98 \%$ in literature), as well as CTXM- TEM+ SHV + gene combination $(47.06 \%$ vs $3.42 \%$ in literature; Hayakawa et al., 2013; Manoharan et al., 2011). This study's finding of higher bacterial plasmid gene frequency could be explained by the use of different material, i.e., the higher plasmid gene frequency in wound infections compared to urinary tract infections and bacteria strains; higher plasmid gene frequency in ESBL producing $K$. pneumoniae compared to ESBL producing E. coli; as well as geographical differences in plasmid gene expression among different populations worldwide (Alekshun \& Levy, 2007; Shaikh et al., 2015; Lee et al., 2012; Cantón et al., 2008). There is a considerable geographical difference in ESBL producing microorganisms and plasmid gene frequency in European countries. These differences also exist within countries and vary significantly between hospitals (Paterson \& Bonomo, 2005). Similar data, confirming higher bacterial plasmid gene frequency in Latvia were found in another study by Pai et al. (see Lillo et al., 2014).

Only some of these studies analyzed the differences between male and female patients with ESBL producing Enterobacteriaceae infection, and of these, findings indicated that patients with E. coli and plasmid CTX-M gene presence were more likely to be male patients around the age of 68.2 years (Hayakawa et al., 2013). Prior to this, plasmid gene combination association with demographic factors had not been described in the literature.

Other studies have demonstrated higher plasmid SHV gene frequency in the K. pneumoniae group, compared to the $E$. coli group (Manoharan et al., 2011), as well as slightly higher plasmid CTX-M gene frequency in the E. coli group and slightly higher plasmid TEM gene frequency in the $K$. pneumoniae group (Kargar et al., 2014; Lin, Hsu, Chen, Huang, \& Lo, 2010).

Until now, plasmid gene combination associated with a certain ESBL producing Enterobacteriaceae strain had not been described in the literature. However, one study had suggested that the three 
plasmid extended-spectrum beta-lactamase gene (CTX-M+ TEM+ SHV+) combination was more frequently found in $K$. pneumoniae whereas other plasmid gene combinations were related to $E$. coli. Nevertheless, statistical significance was not proven by the authors of this study (Manoharan et al., 2011)

The three plasmid extended-spectrum beta-lactamase gene (CTX-M+ TEM+ SHV+) combination has been associated, in various literature sources, with higher antimicrobial resistance, determining resistance to ampicillin, ciprofloxacin, ceftriaxone, cefotaxime, cefexime, aztreonam, and erythromycin (Shaikh et al., 2015; Talukdar et al., 2013). Considering the three plasmid extendedspectrum beta-lactamase gene $(\mathrm{CTX}-\mathrm{M}+\mathrm{TEM}+\mathrm{SHV}+)$ combination in this study occurred more frequently in $K$. pneumoniae and in older patients, as well as the geographical differences found associated with ESBL producing microorganism, plasmid gene frequency, and local resistance patterns, the authors suggest that older patients, who suffer from wound infections caused by ESBL producing $K$. pneumoniae may benefit from empirical therapy with broad spectrum antibacterial therapy.

\section{Conclusion}

Based on this study's findings the following is concluded:

1. Geographical differences concerning Enterobacteriaceae producing strains and plasmid gene frequency exist with higher $K$. pneumoniae and bacterial plasmid gene frequency in Latvia compared to other European countries.

2. Klebsiella pneumoniae is more often present with plasmid SHV+ extended-spectrum betalactamase gene and the three plasmid extended-spectrum beta-lactamase gene (CTX-M+ $\mathrm{TEM}+\mathrm{SHV}+$ ) combination, as compared to E. coli.

3. Older patients with ESBL producing Enterobacteriaceae infection, more often, present with the three plasmid extended-spectrum beta-lactamase gene (CTX-M+ TEM+ SHV+) combination, compared to younger patients with this infection.

\section{References}

Alekshun, M. N., \& Levy, S. B. (2007). Molecular Mechanisms of Antibacterial Multidrug Resistance. Cell, 128(6), 10371050. http://doi.org/10.1016/j.cell.2007.03.004

Cantón, R., Novais, a., Valverde, a., Machado, E., Peixe, L., Baquero, F., \& Coque, T. M. (2008). Prevalence and spread of extended-spectrum $\beta$-lactamase-producing Enterobacteriaceae in Europe. Clinical Microbiology and Infection, 14(SUPPL. 1), 144-153. http://doi.org/10.1111/j.1469-0691.2007.01850.x

Coque, T. M., Baquero, F., \& Canton, R. (2008). Increasing prevalence of ESBL-producing Enterobacteriaceae in Europe. Euro Surveillance : Bulletin Europ? ?en Sur Les Maladies Transmissibles = European Communicable Disease Bulletin, 13(47), 1-11. http://doi.org/10.1128/AAC.49.7.2693-2700.2005

Edelstein, M., Pimkin, M., Palagin, I., Edelstein, I., \& Stratchounski, L. (2003). Prevalence and Molecular Epidemiology of CTX-M Extended-Spectrum -Lactamase-Producing Escherichia coli and Klebsiella pneumoniae in Russian Hospitals. Antimicrobial Agents and Chemotherapy, 47(12), 3724-3732. http://doi.org/10.1128/AAC.47.12.3724-3732.2003

EUCAST: Resistance mechanisms (2015). Retrieved December 20, 2015, from

http://www.eucast.org/resistance_mechanisms/

Hayakawa, K., Gattu, S., Marchaim, D., Bhargava, A., Palla, M., Alshabani, K., \& Kaye, K. S. (2013). Epidemiology and risk factors for isolation of Escherichia coli producing CTX-M-type extended-spectrum $\beta$-lactamase in a large U.S. Medical Center. Antimicrobial Agents and Chemotherapy, 57(8), 4010-8. http://doi.org/10.1128/AAC.02516-12

Kargar, M., Kargar, M., Jahromi, M. Z., Najafi, A., \& Ghorbani-Dalini, S. (2014). Molecular detection of ESBLs production and antibiotic resistance patterns in Gram negative bacilli isolated from urinary tract infections. Indian Journal of Pathology \& Microbiology, 57(2), 244-8. http://doi.org/10.4103/0377-4929.134688

Kassakian, S. Z., \& Mermel, L. a. (2014). Changing epidemiology of infections due to extended spectrum beta-lactamase producing bacteria. Antimicrobial Resistance and Infection Control, 3(1), 9. http://doi.org/10.1186/2047-2994-3-9

Kolar, M., Latal, T., Cermak, P., Bartonikova, N., Chmelarova, E., Sauer, P., \& Kesselova, M. (2006). Prevalence of extended-spectrum ??-lactamase-positive Klebsiella pneumoniae isolates in the Czech Republic. International Journal of Antimicrobial Agents, 28(1), 49-53. http://doi.org/10.1016/j.ijantimicag.2006.02.012

Lee, J. H., Bae, I. K., \& Lee, S. H. (2012). New definitions of extended-spectrum $\beta$-lactamase conferring worldwide emerging antibiotic resistance. Medicinal Research Reviews, 32(1), 216-32. http://doi.org/10.1002/med.20210 
Lillo, J., Pai, K., Balode, A., Makarova, M., Huik, K., Kõljalg, S., \& Sepp, E. (2014). Differences in Extended-Spectrum Beta-Lactamase Producing Escherichia coli Virulence Factor Genes in the Baltic Sea Region, 2014.

Lin, C. F., Hsu, S. K., Chen, C. H., Huang, J. R., \& Lo, H. H. (2010). Genotypic detection and molecular epidemiology of extended-spectrum beta-lactamase-producing Escherichia coli and Klebsiella pneumoniae in a regional hospital in central Taiwan. Journal of Medical Microbiology, 59(Pt 6), 665-71. http://doi.org/10.1099/jmm.0.015818-0

Manoharan, A., Premalatha, K., Chatterjee, S., \& Mathai, D. (2011). Correlation of TEM, SHV and CTX-M extendedspectrum beta lactamases among Enterobacteriaceae with their in vitro antimicrobial susceptibility. Indian Journal of Medical Microbiology, 29(2), 161-4. http://doi.org/10.4103/0255-0857.81799

Mehrgan, H., \& Rahbar, M. (2008). Prevalence of extended-spectrum ??-lactamase-producing Escherichia coli in a tertiary care hospital in Tehran, Iran. International Journal of Antimicrobial Agents, 31(2), 147-151. http://doi.org/10.1016/j.ijantimicag.2007.09.008

Mengistu, A., Gaeseb, J., Uaaka, G., Ndjavera, C., Kambyambya, K., Indongo, L., \& Sagwa, E. (2013). Antimicrobial sensitivity patterns of cerebrospinal fluid (CSF) isolates in Namibia: implications for empirical antibiotic treatment of meningitis. Journal of Pharmaceutical Policy and Practice, 6, 4. http://doi.org/10.1186/2052-3211-6-4

Moor, C. T., Roberts, S. A., Simmons, G., Briggs, S., Morris, A. J., Smith, J., \& Heffernan, H. (2008). Extended-spectrum beta-lactamase (ESBL)-producing enterobacteria: factors associated with infection in the community setting, Auckland, New Zealand. The Journal of Hospital Infection, 68(4), 355-62. http://doi.org/10.1016/j.jhin.2008.02.003

Paterson, D. L., \& Bonomo, R. A. (2005). Extended-Spectrum -Lactamases: a Clinical Update. Clinical Microbiology Reviews, 18(4), 657-686. http://doi.org/10.1128/CMR.18.4.657-686.2005

Peralta, G., Lamelo, M., Alvarez-García, P., Velasco, M., Delgado, A., Horcajada, J. P., \& Capdevila, J. A. (2012). Impact of empirical treatment in extended-spectrum beta-lactamase-producing Escherichia coli and Klebsiella spp. bacteremia. A multicentric cohort study. BMC Infectious Diseases, 12(1), 245. http://doi.org/10.1186/1471-2334-12-245

Poirel, L., Naas, T., \& Nordmann, P. (2008). Genetic support of extended-spectrum ??-lactamases. Clinical Microbiology and Infection, 14(SUPPL. 1), 75-81. http://doi.org/10.1111/j.1469-0691.2007.01865.x

Ruiz de Alegría, C., Rodríguez-Baño, J., Cano, M. E., Hernández-Bello, J. R., Calvo, J., Román, E., \& Martínez-Martínez, L. (2011). Klebsiella pneumoniae strains producing extended-spectrum beta-lactamases in Spain: microbiological and clinical features. Journal of Clinical Microbiology, 49(3), 1134-6. http://doi.org/10.1128/JCM.02514-10

Sasirekha, B. (2013). Prevalence of ESBL, AmpC $\beta$-lactamases and MRSA among uropathogens and its antibiogram. Retrieved from http://eldorado.tu-dortmund.de/handle/2003/30327

Shaikh, S., Fatima, J., Shakil, S., Rizvi, S. M. D., \& Kamal, M. A. (2015). Antibiotic resistance and extended spectrum betalactamases: Types, epidemiology and treatment. Saudi Journal of Biological Sciences, 22(1), 90-101. http://doi.org/10.1016/j.sjbs.2014.08.002

Spadafino, J. T., Cohen, B., Liu, J., \& Larson, E. (2014). Temporal trends and risk factors for extended-spectrum betalactamase-producing Escherichia coli in adults with catheter-associated urinary tract infections. Antimicrobial Resistance and Infection Control, 3(1), 2012-2015. http://doi.org/10.1186/s13756-014-0039-y

Tacconelli, E., Cataldo, M. A., Dancer, S. J., De Angelis, G., Falcone, M., Frank, U., \& Cookson, B. (2014). ESCMID guidelines for the management of the infection control measures to reduce transmission of multidrug-resistant Gram-negative bacteria in hospitalized patients. Clinical Microbiology and Infection: The Official Publication of the European Society of Clinical Microbiology and Infectious Diseases, 20 Suppl 1, 1-55. http://doi.org/10.1111/1469-0691.12427

Takaba, K., Shigemura, K., Osawa, K., Nomi, M., Fujisawa, M., \& Arakawa, S. (2014). Emergence of extended-spectrum ??lactamase-producing Escherichia coli in catheter-associated urinary tract infection in neurogenic bladder patients. American Journal of Infection Control, 42(3), e29-e31. http://doi.org/10.1016/j.ajic.2013.11.018

Talukdar, P. K., Rahman, M., Rahman, M., Nabi, A., Islam, Z., Hoque, M. M., \& Islam, M. A. (2013). Antimicrobial resistance, virulence factors and genetic diversity of Escherichia coli isolates from household water supply in Dhaka, Bangladesh. PloS One, 8(4), e61090. http://doi.org/10.1371/journal.pone.0061090

The New $\beta$-Lactamases - NEJM. (2015). Retrieved June 4, 2015, from http://www.nejm.org/doi/full/10.1056/NEJMra041359

Tumbarello, M., Sanguinetti, M., Montuori, E., Trecarichi, E. M., Posteraro, B., Fiori, B., \& Spanu, T. (2007). Predictors of mortality in patients with bloodstream infections caused by extended-spectrum-beta-lactamase-producing Enterobacteriaceae: importance of inadequate initial antimicrobial treatment. Antimicrobial Agents and Chemotherapy, 51(6), 1987-94. http://doi.org/10.1128/AAC.01509-06

Wu, T. L., Siu, L. K., Su, L. H., Lauderdale, T. L., Lin, F. M., Leu, H. S., \& Ho, M. (2001). Outer membrane protein change combined with co-existing TEM-1 and SHV-1 beta-lactamases lead to false identification of ESBL-producing Klebsiella pneumoniae. The Journal of Antimicrobial Chemotherapy, 47(6), 755-61. Retrieved from http://www.ncbi.nlm.nih.gov/pubmed/11389107 